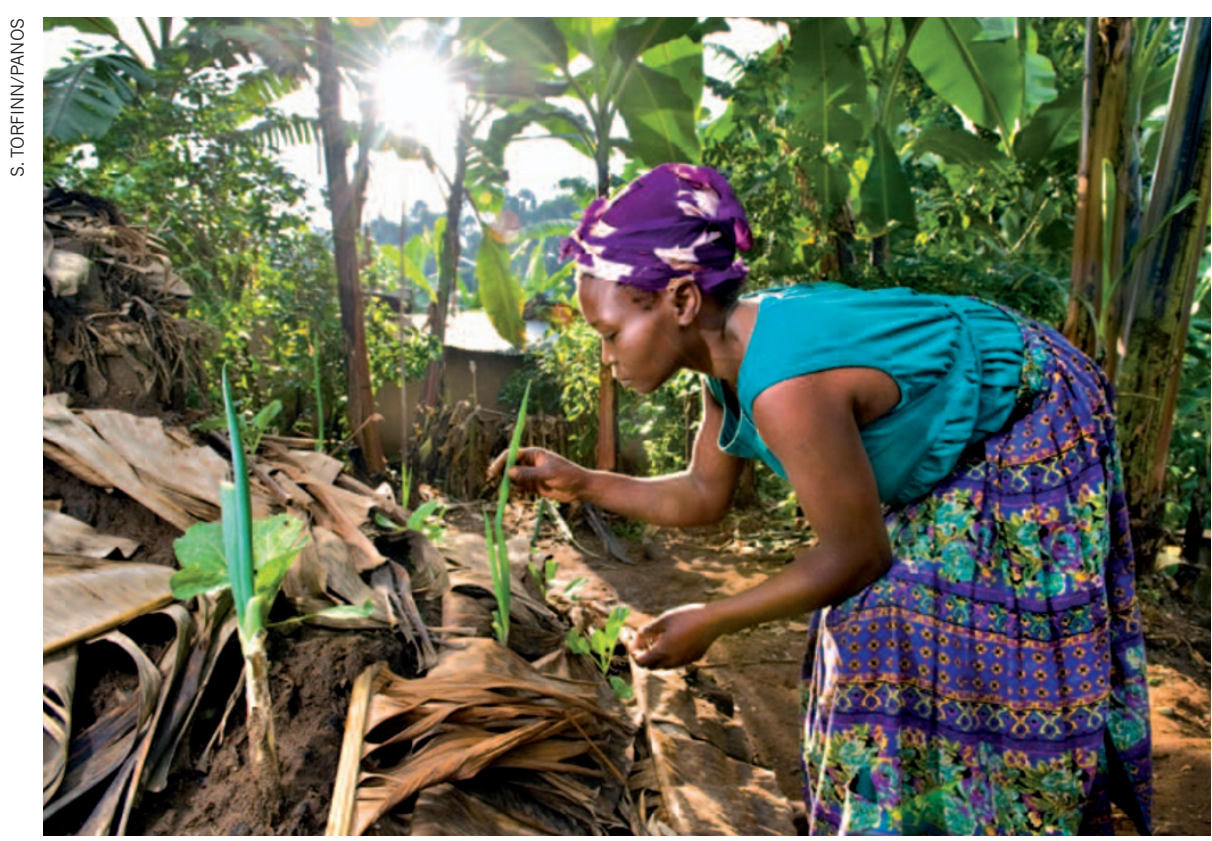

Training for Africa's women farmers is vital if the continent is to shift to more sustainable agriculture.

\title{
AGRICULTURE
}

\section{A bowl half full}

\section{Calestous Juma's vision for African farming is refreshingly optimistic, finds Camilla Toulmin.}

$\mathrm{I}^{\mathrm{s}}$ nnovation, entrepreneurship and investment lie at the heart of Calestous

Juma's upbeat assessment of the future of African agriculture. In The New Harvest, Juma, an expert in international development, shows how agricultural science, the business of development and the institutions that shape food markets are transforming the opportunities of farmers and traders across the continent.

His optimism is refreshing - a welcome antidote to the pessimistic view of African development of previous decades. Forecasts predict annual economic growth of 5-8\% for many African countries over the next few years. But important questions remain over how the power and benefits that will come from this growth will be distributed.

Juma's book is timely. The renewed volatility in food and fuel prices is prompting worries about food security and the associated risks of political turmoil, as seen in North African countries. Agriculture is firmly back on the international agenda. Rising food prices are bad for poor people, but bring extra revenue for those producing a surplus. Agricultural land is now an asset, prompting a 'land grab' by companies and foreign governments who have taken advantage of cheap land and poorly governed

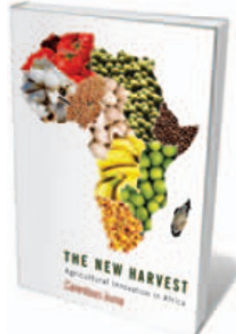

The New Harvest: Agricultural Innovation in Africa

CALESTOUS JUMA

Oxford University

Press: 2011.296 pp. $\$ 19.95$ natural-resource rights in parts of Africa.

Juma sees regional economic organizations, such as the Common Market for Eastern and Southern Africa (COMESA), as essential in promoting innovation. By aggregating markets and pooling research resources, benefits can be spread among countries, giving small African nations the economies of scale needed to compete and diversify. Although many regional bodies have been criticized for the gap between their aspirations and achievements, and for their overlapping and competing mandates, Juma is positive about their future role, citing cross-border planning and investment in electricity and gas distribution as an example of good practice.

The book is filled with examples of improvements in food and farming systems, where governments have energized local groups. For instance, the University of Agriculture in Abeokuta, Nigeria, and the food

company Nestlé are working together on soya beans and cassava to improve varieties and productivity, thus increasing incomes for Nigerian farmers. Similar projects have enhanced the take-up of improved rice varieties with higher yield and greater stress resistance in Benin, Ghana and Ethiopia.

Philosophically, Juma takes an eclectic approach: he draws on three strands of argument. First, he embraces the opportunities of an outward-looking, market-oriented farming system in which productivity grows through new science-based breeds and seeds. Second, he accepts the need for food security and the strengthening of local knowledge networks, indigenous systems and varieties. Third, he acknowledges that a combination of population growth and lack of innovation has led to stagnant conditions and African reliance on food imports.

Juma recognizes that past governments have drained the agriculture industry of revenues in favour of building up other sectors. Long-term neglect has meant that irrigation covers only $4 \%$ of Africa's cropped area, and fertilizer use in the continent is one-tenth of the world average. But, he argues, the latest generation of African leaders offers a greater commitment to invest in agriculture.

Juma is keen on applying technology to agriculture. He looks to advances in tissue culture and breeding, such as using a genetic or morphological marker to select for desirable traits, and to cheaper genetic mapping of Africa's crops for improved productivity. He brushes aside sceptics' reservations about genetically modified crops and sees instead the promise of lower pesticide use and higher yields that companies such as Monsanto have brought to smallholder farmers growing cotton in Burkina Faso and South Africa. But he does not address the main concern about genetically modified crops, namely the concentration of economic power held by a few major agrochemical companies.

He lauds the now-ubiquitous mobile telephone for addressing old problems in new ways, and for transforming people's access to market information and financial services. But Juma reminds us that fundamental investments are still needed in basic infrastructure, such as road networks, to get supplies to farmers and harvests to market. Reducing transport costs would greatly increase farmers ability to respond to market demand.

To foster innovation, Juma champions a "cluster approach", in which groups from government, the private sector, civil society and researchers come together in a variety of partnerships to work on common prob-

- NATURE.COM Call for a global network for farming practices:

go.nature.com/mbgkag lems, building trust through proximity. In the past, he explains, the state was too dominant: public-sectorled approaches to 
agricultural research assumed a pipeline of technology from lab to farm. In future, the farmer should be seen as a co-producer of research, not a recipient of handeddown technology. China is fostering this approach. Juma gives a good illustration of the boom in vegetable production in China's Shandong province, where local government has encouraged a range of businesses and market development.

With its climate changing and population growing, Africa will have to produce food under greater environmental pressure. He argues that agriculture needs to shift towards more sustainable farming patterns, which are also more knowledgeintensive. This will require governments and societies to address the deficit in training and access to education, particularly for women, who are the backbone of food production in many African farming communities. For example, the non-governmental Uganda Rural Development and Training programme teaches farming methods using a curriculum that focuses on building strong female agricultural leaders.

Weak infrastructure and scarce land and water may be harder to overcome than Juma suggests. A few African governments recognize the potential of agriculture to drive economic growth and reduce poverty, but there is still a long way to go. Climate-change impacts could be hugely damaging unless urgent work is done to construct resilient local and national systems. A focus on the benefits of global markets, inward investment and modern technology needs to be balanced by consideration for who gains and who loses.

Concerns are already being raised by farmers' associations about large-scale investment in agricultural land, in 'landgrab' deals negotiated by few people. In Mali, farmers want a moratorium on large land allocations, and have issued a call to remind the government that land, water, forests and natural resources constitute national assets for all citizens. Other investment models, such as contract farming or joint ventures with local farmers, should be considered. Transparency is also needed to ensure that investors undertake their contractual obligations and do not engage in speculation.

Like Juma, I see the glass as half full, but there are many challenges ahead. Nevertheless, The New Harvest reminds us that by working with farmers, nongovernmental organizations, government and business, science has the potential to transform Africa's food security.

Camilla Toulmin is director of the International Institute for Environment and Development, London, UK. e-mail:camilla.toulmin@iied.org

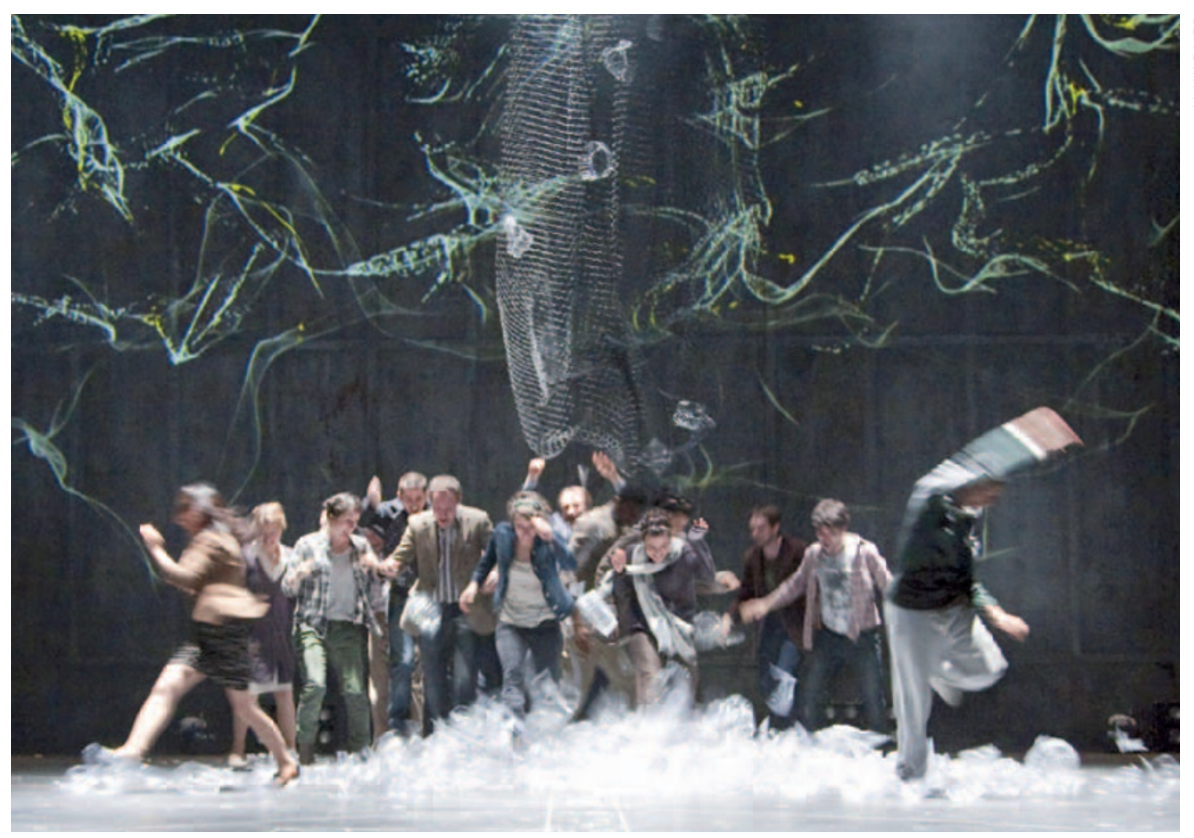

Greenland gives an alarming assessment of climate change in a production as complex as the topic itself.

THEATRE

\section{Poles apart on climate}

\section{Two contrasting plays highlight the difficulties of putting global warming on stage, finds Kerri Smith.}

$\mathrm{F}$ Terocious debate has polarized the issue of climate change - and two plays currently running in London reveal many facets of those arguments. Greenland is a rational but disjointed assessment of how urgent and alarming our predicament is, whereas The Heretic is an entertaining family drama with a climate sceptic as the protagonist.

Greenland, at the National Theatre, is a production almost as complex and unwieldy as climate change itself. It weaves together several narratives: a student-teacher becomes a green activist; a birdwatcher witnesses habitat change in the Arctic; a couple argue over their individual contributions to global warming. These unfolding tales share the stage with falling rain and a remarkably life-like model of a polar bear.

The most engaging scenes involve the play's climate modeller, Ray, and a government official, Phoebe, sent to gather data ahead of the December 2009 climate negotiations in Copenhagen. She arrives at the lab after he has worked all night on his model; he is reticent to let her see his work before it has been peer reviewed. When they get to Copenhagen, we are given a sense of the convoluted processes involved in drafting an international policy agreement when a dozen weighty volumes fall
Greenland

MOIRA BUFFINI, MATT CHARMAN, PENELOPE

SKINNER AND JACK THORNE

National Theatre, London. Until 2 April 2011.

\section{The Heretic}

RICHARD BEAN

Royal Court Theatre, London. Until 19 March 2011.

from the ceiling and land with a thud.

But the multitude of characters and jumbled storylines make this play difficult to follow. Laced with statistics and quotes, it feels at times like a lecture. Greenland's four writers - Moira Buffini, Matt Charman, Penelope Skinner and Jack Thorne - spent months researching the topic by interviewing experts, activists and journalists. The team hoped to convey the complexity of the issue, says the play's artistic director, Ben Power. "We're trying to explore the feeling of powerlessness," he adds. What they actually depict, in shoehorning all their research onto the stage, is confusion.

Richard Bean's The Heretic is easier to watch, with its linear storyline, entertaining characters and laughout-loud dialogue. But its factual errors will infuriate some scientists.

The play centres on

DNATURE.COM Brian Wynne's review of Merchants of Doubt. go.nature.com/tcsjbk 